\title{
Arthropods associated with a Bombus pauloensis (Hymenoptera: Apidae: Bombini) nest in the Sabana of Bogotá (Colombia)
}

\section{Artrópodos asociados a un nido de Bombus pauloensis (Hymenoptera: Apidae: Bombini) en la Sabana de Bogotá (Colombia)}

\author{
Francisco Javier Posada-Flórez'; Lorena Téllez-Farfán²
}

\begin{abstract}
${ }^{1}$ Agronomist Engineer, Ph.D. Bee Research Laboratory, Agricultural Research Center, United States Department of Agriculture, Beltsville - Maryland, United States of America; e-mail: fjavierposada@gmail.com; (D) https://orcid.org/0000-0002-7349-2240

${ }^{2}$ Professional in Environmental Sciences, Biology M.Sc. Universidad Nacional de Colombia, Laboratorio de Investigaciones en abejas, LABUN. Bogotá, D.C., Colombia; e-mail: tllezlorena@gmail.com; (D) https://orcid.org/0000-0001-5722-1339
\end{abstract}

How to cite: Posada-Flórez, F.J.; Téllez-Farfán, L. 2021. Arthropods associated with a Bombus pauloensis (Hymenoptera: Apidae: Bombini) nest in the Sabana of Bogotá (Colombia). Rev. U.D.C.A Act. \& Div. Cient. 24(1):e1590. http://doi.org/10.31910/rudca.v24. $\mathrm{n} 1.2021 .1590$

Open access article published by Revista U.D.C.A Actualidad \& Divulgación Científica, under Creative Commons License CC BY-NC 4.0

Official publication of the Universidad de Ciencias Aplicadas y Ambientales U.D.C.A, University, Accredited as a High-Quality Institution by the Colombian Ministry of Education.

Received: July 6, 2020 Accepted: April 28, 2021 Edited by: Helber Adrian Arévalo Maldonado

\begin{abstract}
Bumblebees are important natural pollinators due to their services to wild and cultivated plants. They commonly nest in cavities in the ground where they are exposed to numerous organisms or interact with them. One Bombus pauloensis nest in the Sabana of Bogotá (Colombia) was transferred to an artificial nest and relocated close to a honeybee apiary after the original nest was threatened by an intentional fire. The objective was to preserve the colony and simultaneously identify arthropods associated with a bumblebee nest as this is poorly studied in Colombia. Samples of the organisms found in the bumblebees' nest were collected for taxonomic identification. Several commensal, scavenger and parasitic organisms were found, including Antherophagus sp. (Coleoptera: Crytophagidae), wireworm beetles (Coleoptera: Elateride), Fannia canicularis (Diptera: Fanniidae), and mites of genera Parasitellus and
\end{abstract}

Pneumolaelaps. This is the first report of other organisms besides Antherophagus from a B. pauloensis nest in Colombia.

Keywords: Bumblebee; Natural nest; Parasites; Detritivores; Commensal.

\section{RESUMEN}

Los abejorros son polinizadores importantes en la naturaleza, debido a que prestan su servicio a plantas silvestres y cultivadas. Naturalmente, anidan en cavidades en el suelo, donde se pueden exponer a una gran variedad de organismos o interactuar con estos. Un nido de Bombus pauloensis en la Sabana de Bogotá fue transferido a un nido artificial y reubicado cerca de un apiario, debido a que el nido original fue quemado intencionalmente. Se tuvo por objetivo 
preservar la colonia e identificar los artrópodos asociados, ya que son poco estudiados en Colombia. Se tomaron muestras de los organismos encontrados en el nido, para determinación taxonómica. Varios organismos con hábitos comensales, descomponedores y parásitos se encontraron, incluyendo Antherophagus sp. (Coleoptera: Crytophagidae), cucarrones del gusano alambre (Coleoptera: Elateride), Fannia canicularis (Diptera: Fanniidae) y ácaros de los géneros Parasitellus y Pneumolaelaps (Acarina). Este es el primer reporte de otros organismos, diferentes de Antherophagus, para un nido de B. pauloensis, en Colombia.

Palabras clave: Abejorros; Nido natural; Parásitos; Detritívoros; Comensales.

\section{INTRODUCTION}

The Bombus genus (Hymenoptera: Apidae: Bombini) consists of nearly 250 species worldwide (Williams et al. 2008) and is recognized by its potential as a pollinator in certain crops, especially solanaceous and some ericaceous plants (Delaplane \& Mayer, 2000; Goulson, 2010; Abrol, 2012). The bees of this genus build underground or ground-level nests using hollow cavities made by other organisms or make domes using branches and leaves (Cameron et al. 1999; Michener, 2007; Goulson, 2010). Worldwide, there is a great concern regarding the health of bumblebee and other pollinator populations, since a food shortage caused by the lack of pollinators could compromise human wellbeing (Potts et al. 2010; Bommarco et al. 2013).

Bumblebee populations can be positively or negatively impacted by other organisms. These organisms have been primarily recorded from nests, foragers, workers, and queens (González et al. 2004; Goulson, 2010). The organisms associated with bumblebees and their nests could interact with them in different ways, being parasites, predators, commensals, detritivores or scavengers (Goulson, 2010). Arthropods such as beetles, flies and mites have been reported inside bumblebee nests (Alford, 1978; Goulson, 2010); but worldwide their geographical distributions and function are poorly understood.

Bumblebees have a great diversity of natural enemies with many records made mainly in Europe, New Zealand, North and South America (Husband \& Brown, 1976; Donovan \& Wier, 1978; PrysJones \& Corbet, 1991; Goulson, 2010; Maggi et al. 2011; Gamboa et al. 2015; Revainera et al. 2014; 2019; 2020; Plischuk et al. 2020). Even though natural enemies of bumblebees have been studied for many years, it was only after the development of artificial rearing, mass production and international commercialization between 1960 and 1980 (Velthuis \& Van Doorn, 2006), that the research on bumblebee pests, parasites and pathogens received great attention by sanitary agencies and conservationist organizations. These institutions aim to reduce the risks posed by the introduction of invasive organisms, such as foreign bumblebee species used for pollination in greenhouses and orchard crops (Prys-Jones \& Corbet, 1991; Goka et al. 2001; Morales, 2007; Williams \& Osborne, 2009; Goulson 2010; Hatfield et al. 2012).
Natural enemies of bumblebees have mostly been reported attacking bumblebee nests and adults. Vertebrates such as badgers, skunks, foxes, moles, weasels, shrews, voles, minks and mice are the most common natural enemies that have been reported attacking nests (Prys-Jones \& Corbet, 1991; Goulson, 2010). Records of natural enemies attacking adults include predators such as birds, spiders, robber flies (Diptera: Asilidae) and the wasp Philanthus bicinctus (Hymenoptera: Crabronidae).

Husband \& Brown (1976) reported more than 50 species of arthropods, including insects and mites, associated with bumblebee nests in USA and Europe. The way these arthropods impact bumblebee colonies is poorly understood. They could play a role recycling nest debris and bumblebee corpses that accumulate inside the nest, as bumblebees themselves do not have the cleaning behavior of other social insects like the honeybees that remove remains from their nest. Mites establish strong associations with bumblebee nests and adults, but little is known about their role and authors only report them as either being phoretic or parasites (Maggi et al. 2011; Klimov et al. 2016). Other group of organisms associated with bumblebee colonies are nematodes, which have been shown to impair the queen's reproduction (Prys-Jones \& Corbet, 1991).

The main concern about organisms associated with bumblebees, in both natural and artificial rearing settings, is the introduction of invasive species, which can spill over into their habitat competing for resources like nesting sites and food, impacting native bumblebee species and spreading pathogens such as fungi, protozoa, nematodes, and viruses. Invasive species also include arthropods, which have been found attacking bumblebee colonies under laboratory and field conditions. Examples include the bumblebee wax moth, Aphomia sociella (L.) (Lepidoptera: Pyralidae), which was first reported in Europe and introduced to USA and Canada (BugGuide, 2020), the Indian meal moth Plodia interpunctella (Hübner, 1813) and the greater wax moth, Galleria mellonella (L.) (Lepidoptera: Pyralidae), which were found in rearing facilities (Kwon et al. 2003; Williams, 1997) and the small hive beetle Aethina tumida Murray (Coleoptera: Nitidulidae) that was found in the field (Spiewok \& Neumann, 2006; Hoffmann et al. 2008).

In Colombia, Antherophagus (Coleoptera: Cryptophagidae) beetles have been reported in association with nests of Bombus pauloensis Friese 1913 (formerly recognized as B. atratus Franklin 1913; see Moure \& Melo, 2012) (Roubik \& Wheeler, 1982; González et al. 2004). This species is probably the most common representative of the genus Bombus in Colombia given its distribution and abundance in entomological collections (Liévano et al. 1991; Téllez-Farfán \& Posada-Flórez, 2013). In this work, we report the organisms associated with a B. pauloensis nest found in a field in the Sabana of Bogotá, Colombia.

\section{MATERIALS AND METHODS}

We collected and relocated a B. pauloensis nest that was found in a field, on the slope of a deep drainage ditch on the Thomas van der Hammen Natural Reserve in the Sabana of Bogotá (Colombia) 
(4 48' 10.36" N; 74 03' 03.45" W) (Figure 1a). Relocation of the nest was necessary because landscape workers were afraid of being stung and set fire to the nest to eliminate the colony. The nest was transferred to a wooden box, placed inside a styrofoam box for temperature insulation and then relocated close to a honeybee apiary that was also located in the Thomas van der Hammen Reserve. The relocation process was done at 6:00am, when all the bumblebees were still inside the nest, making it easier to collect all adults and cells with brood and food. The colony contained approximately 20 queens, 600 females and 200 males, which indicated that it was in the reproductive phase (Prys-Jones \& Corbet, 1991). Inside the nest, we found several layers of cells and substantial debris, including plastic bags, nylon cords and leaves of dry grass, suggesting these bees probably took over a mouse nest and used those materials to insulate the nest.

While digging out the Bombus colony, we observed the presence of beetles, flies, and mites inside the nest (Figure 1b). Samples of those organisms were collected and stored in 95\% ethanol and transfer to the laboratory for further observation, identification, and photo documentation. Morphology description, DNA analysis and expert consultation were used to identify the associated organisms found (Peterson, 1957; Arnett et al. 2002; Nelson et al. 2007; Majka \& Langor, 2010; Klimov et al. 2016).

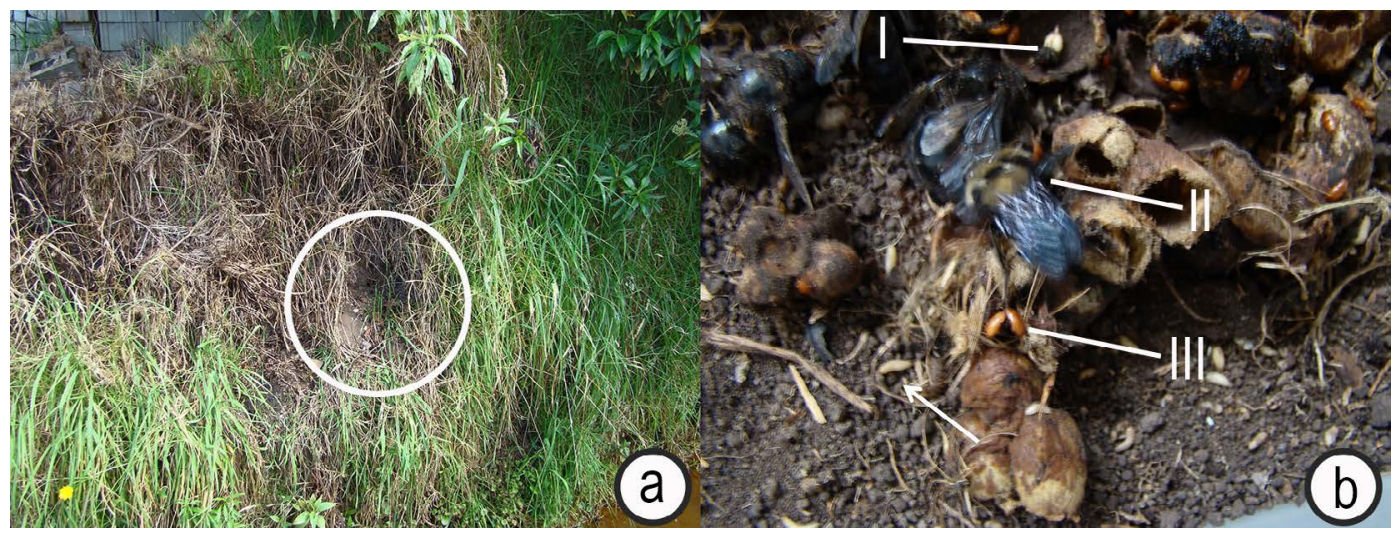

Figure 1. a. Location of the bumblebee nest that was relocated; circle shows the nest entrance; b. B. pauloensis nest showing fly larvae (I), bumblebees (II), and beetles (III).

The fly species was identified morphologically (Peterson, 1957) and molecularly using genomic DNA, which was extracted from half the body of an adult specimen using the DNeasy tissue kit (Qiagen Inc., Valencia, CA) according to manufacturer's instructions. One $\mu \mathrm{L}$ of extracted DNA was used as a template to amplify the Citochrome C Oxidase (COI) barcoding region using primers LCO1490-L and HCO2198-L (Nelson et al. 2007). A polymerase chain reaction (PCR) was carried out in a final volume of $50 \mu \mathrm{L}$, using the EmeraldAmp $\mathbb{R}$ GT-PCR Master Mix (Takara Bio Inc., Mountain View, CA) following PCR primer conditions described by Nelson et al. (2007). The PCR product was purified and sequenced by Retrogen, Inc. (San Diego, CA) using respective primer pairs. Forward and reverse sequence files were imported into Sequencher 5.0 (GeneCodes, Ann Arbor, MI) and assembled into one contig sequence using default parameters. The sequence was then compared against the NCBI nucleotide BLAST (nr/nt) database (http:/ / blast.ncbi.nlm.nih.gov) using the megablast algorithm. The barcode sequence obtained in this study was deposited in the GenBank database (http://www.ncbi.nlm.nih.gov/genbank/ index.html) under accession number KF751463.

For taxonomic identification of mites, samples were sent to Dr. Barry O' Connor, from the University of Michigan. The identification of beetles was based on taxonomic keys and descriptions provided by Majka \& Langor (2010) and Arnett et al. (2002).

\section{RESULTS AND DISCUSSION}

One hundred thirty Antherophagus sp. beetle adults, larvae and pupae were found in the $B$. pauloensis nest (Figure 2a-c). Adult beetles were actively crawling, but the most remarkable observation was that they were attached to B. pauloensis adult legs and antenna and did not dislodge easily when the bumblebees moved away, or when placed in alcohol or into a freezer (Figure 2d). These organisms were previously noted by Roubik \& Wheeler (1982) and González et al. (2004), from a B. pauloensis nest in Colombia. The latter authors observed Antherophagus individuals in old combs and debris, and in the upper nest areas looking for workers when the colony was nearly gone. This genus has been reported in other bumblebee and stingless bee (Apidae: Meliponini) nests and has been described as having both phoretic and scavenger behaviors (Wheeler, 1919; Schwartz, 1948; Alford, 1978; Thorp et al. 1983; Goulson, 2010). Alford (1978) and Goulson (2010) reported A. nigricornis associated with bumblebee nests. Antherophagus, also known as flower beetles or silken fungus beetles were found in a nearby honeybee hive alongside pollen and wax on a greased sticky board placed on the bottom of the hive to trap Varroa destructor (Acari: Varroidae) mites. Flower beetles may have been brought to the honeybee hive on bees that were observed robbing the rescued $B$. pauloensis nest. 


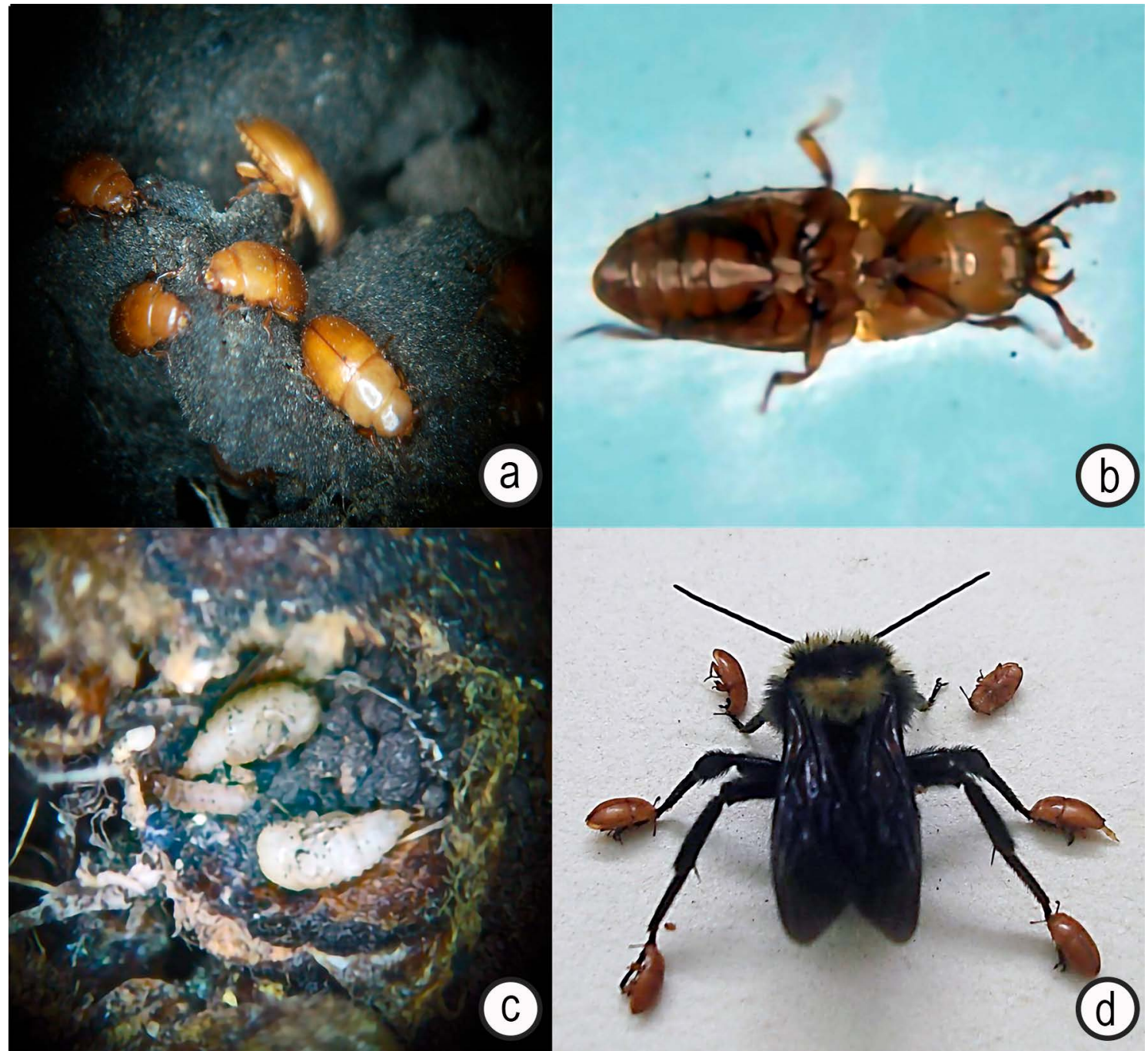

Figure 2. Antherophagus beetles found in the B. pauloensis nest. a. Adults; b. Ventral view of adult beetle; c. Larvae and pupae; d. Antherophagus adult beetles attached to the bumblebee legs.

Other arthropods present in the $B$. pauloensis nest were wireworm (Coleoptera: Elateridae) larvae and adults, morphologically identified to family level. Elateridae larvae are known pests of several crops and can also prey upon other insects (Arnett et al. 2002). Their presence in the nest indicates that they may prey on $B$. pauloensis brood, on their associated commensals, or are scavengers.

Adults, pupae, and larvae of Fannia canicularis (Diptera: Fanniidae) were also found in the B. pauloensis nest (Figure 3a-c). The $661 \mathrm{bp}$ COI fragment sequence obtained from the specimen showed $>91 \%$ identity to other COI sequences of the same species (i.e., KY511165, KC617820, and MF511733). Adult flies were not actively flying but rather moving around the cells when the nest was exposed and open. Some specimens lacked wings. Adults and larvae of F. canicularis have been reported in bumblebee nests by Alford (1978) and Goulson (2010). Thorp et al. (1983) reported the genus Fannia as scavengers of bumblebee nests. The Fanniidae family has been reported in other hymenopteran nests such as yellow jacket wasps apparently feeding on debris (Husband \& Brown, 1976; Grzywacz et al. 2012). MacDonald et al. (1980) and Grzywacz et al. (2012) mentioned that the function of Fanniidae on Hymenoptera nests seem to be the recycling of debris that accumulate at the bottom of the nest after becoming wet and moldy, when the colonies are declining at the end of the season in temperate regions.

Mites were also observed crawling actively over the cells and debris of the $B$. pauloensis nest. No mites were observed riding on $B$. pauloensis adults, but they were rather spread throughout the nest. Mites were taxonomically identified by Dr. Barry O' Connor as probable Pneumolaelaps sp. (Mesostigmata: Laelapidae) and Parasitellus sp. (Mesostigmata: Parasitidae). Species of these mites have been reported in Argentina, Uruguay, and Bolivia associated to B. paulensis workers caught with nets in the field or found on bumblebee specimens preserved in entomological collections (Maggi et al. 2011; Revainera et al. 2014; 2019; 2020; Plischuk et al. 2020). 


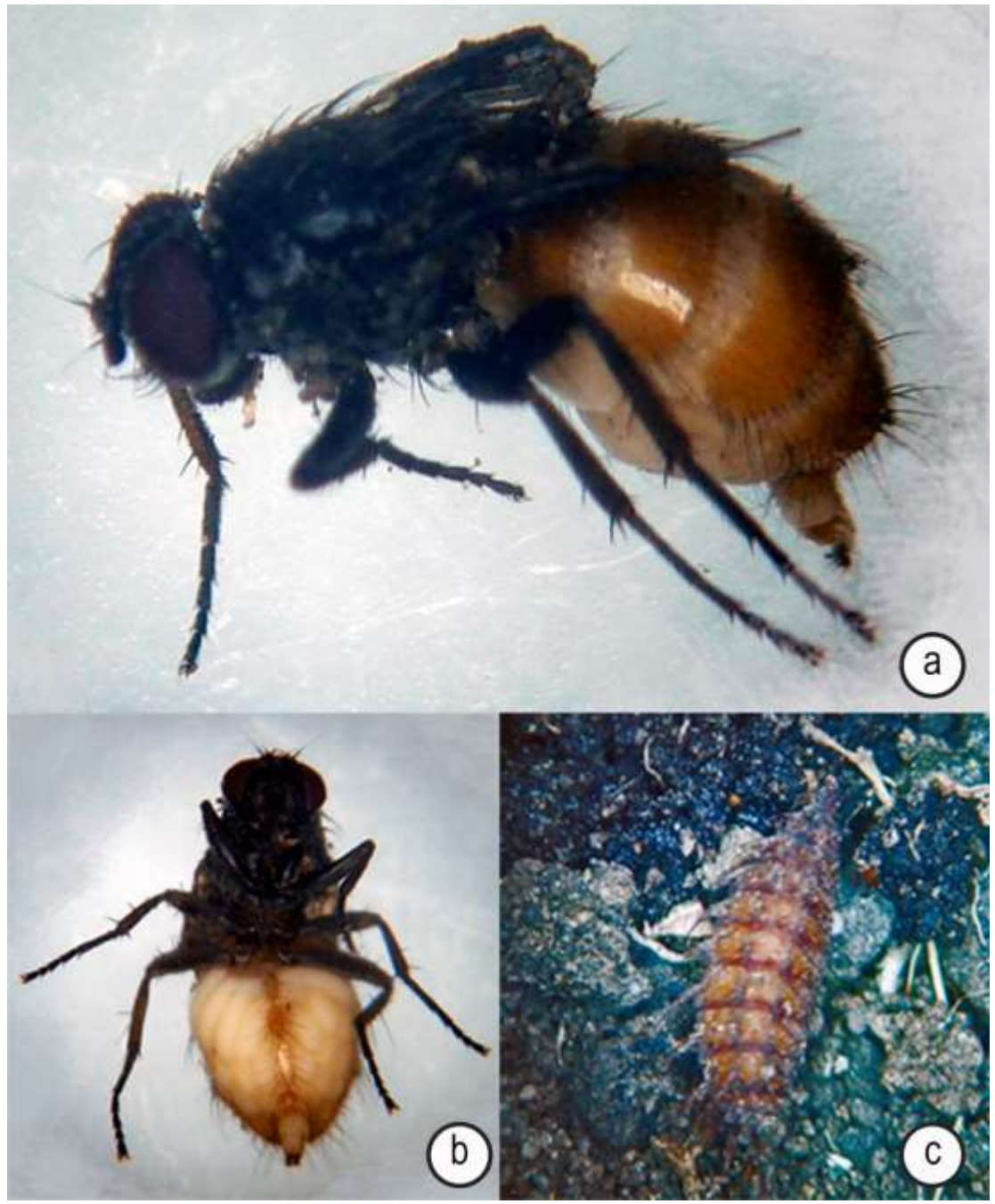

Figure 3. Fannia canicularis. a. Adult, lateral view; b. Adult, ventral view; c. Larva.

Mites of the genus Pneumolaelaps are commonly associated with bumblebees (Hunter \& Husband, 1973; Royce \& Krantz, 1989) and have been reported with a worldwide distribution (Hunter \& Husband, 1973; Royce \& Krantz, 1989; Goulson, 2010; Klimov et al. 2016). In South America, Maggi et al. (2011) reported seven species of mites, including P. longanalis and P. longipilus, that were associated as phoretic of $B$. paulensis. This makes B. pauloensis the studied bumblebee species with the highest diversity of mites reported in South America (Eguaras et al. 1997; Maggi et al. 2011; Revainera et al. 2014, 2019; 2020; Plischuk et al. 2020). Goulson (2010) and Klimov et al. (2016) also reported Pneumolaelaps mites as phoretic with some preferences for Bombus queens, while Royce \& Krantz (1989) proved $P$. longanalis feed on fresh pollen with nectar that bees carry to the nest. However, the consequences of this type of parasitism or commensalism were not evaluated or discussed by the authors.

Goulson (2010), Maggi et al. (2011) and Klimov et al. (2016) also reported Parasitellus as a scavenger mite with obligatory association to bumblebees, present in rearing facilities and with a worldwide distribution. It is important to highlight that the Parasitellus mite collected and identified in this study probably belongs to an undescribed species, which indicates the need to further studying this fauna in Colombia.

From this research the existence of a variety of organisms associated with the B. pauloensis nest found in the Sabana of Bogota (Colombia), which were not causing any negative impact on the bumblebees, was concluded. However, it is necessary to determine the roles and impacts of the associated organisms found under natural nesting conditions to improve the bumblebee's conservation.

Acknowledgements. The authors would like to thank Dr. Monica Pava-Ripoll for helping on the molecular identification of the fly and to Dr. Barry O'Connor for the taxonomic identification of the mites. Also, for reading and improving the manuscript with their comments we would like to thank Dr. Monica Pava-Ripoll, Dr. Jay Evans, Dawn Lopez, and Curtis Rogers. Conflict of interest: The manuscript was prepared and revised by all authors, who declare the absence of any conflict which can put the validity of the presented results in risk. 


\section{REFERENCES}

1. ABROL, D. 2012. Pollination Biology, Biodiversity Conservation and Agricultural Production. Springer Science Business (New York). 792p.

2. ALFORD, D. 1978. The life of the Bumblebee. Northern Bee Books (UK). 80p.

3. ARNETT, R.; THOMAS, M.; SKELLEY, P.; FRANK, J. 2002. American Beetles, Volume II: Polyphaga: Scarabaeoidea through Curculionoidea. CRC Press (Florida).

4. BOMMARCO, R.; KLEIJN, D.; POT'TS, S.G. 2013. Ecological intensification: harnessing ecosystem services for food security. Trends Ecol. Evol. (Netherlands). 28:230-238. https://doi.org/10.1016/j.tree.2012.10.012

5. BUGGUIDE. 2020. Species Aphomia sociella - Bee Moth BugGuide.Net. Available in Internet from: https://bugguide.net/node/view/29899 (accessed 28/09/2020).

6. CAMERON, S.; WHITFIELD, J.; COHEN, M.; THORP, N. 1999. Novel use of walking trails by the Amazonian Bumble Bee, Bombus transversalis (Hymenoptera: Apidae). Univ. Kansas Nat. Hist. Mus. Special Publication (United States). 24:187-193.

7. DELAPLANE, K.; MAYER, D. 2000. Crop pollination by bees. CABI Publishing (United States). 344p.

8. DONOVAN, B.J.; WIER, S.S. 1978. Development of hives for field population increase, and studies on the life cycles of the four species of introduced bumble bees in New Zealand. New Zealand J. Agricultural Research. 21(4):733756.

9. EGUARAS, M.J.; FARINA, J.; MARTÍNEZ, P.A. 1997. Primera cita del género Pneumolaelaps (Acari: Laelapidae) para la región Neotropical. Rev. Soc. Entomol. Argent. 56:1-4.

10. GAMBOA, V.; RAVOET, J.; BRUNAIN, M.; SMAGGHE, G.; MEEUS, I.; FIGUEROA, J.; RIAÑO, D.; DE GRAAF, D.C. 2015. Bee pathogens found in Bombus atratus from Colombia: A case study. J. Invertebr. Pathol. (United States). 129:36-39.

http:/ /dx.doi.org/10.1016/j.jip.2015.05.013

11. GOKA, K.; OKABE, K.; YONEDA, M.; NIWA, S. 2001. Bumblebee commercialization will cause world-wide migration of parasitic mites. Mol. Ecol. (United Kingdom). 10:2095-2099.

https://doi.org/10.1046/j.0962-1083.2001.01323.x
12. GONZÁLEZ, V.; MEJÍA, A.; RASMUSSEN, C. 2004. Ecology and Nesting Behavior of Bombus atratus Franklin in Andean Highlands (Hymenoptera: Apidae). J. Hymenopt. Res. (United States). 13(2):234-242.

13. GOULSON, D. 2010. Bumblebees, Behaviour, Ecology, and Conservation. $2^{\text {nd }}$ Ed. Oxford University Press (United States). 317p.

14. GRZYWACZ, A.; PAPE, T.; SZPILA, K. 2012. Larval morphology of the lesser housefly, Fannia canicularis. Med. Vet. Entomol. (England). 26:70-82. https://doi.org/10.1111/j.1365-2915.2011.00968.x

15. HATFIELD, R.; JEPSEN, S.; MADER, E.; HOFFMAN, S.; SHEPERD, M. 2012. Conserving bumble bees. The Xerxes Society for Invertebrate Conservation (United States). 40p.

16. HOFFMANN, D.; PETTIS, J.S.; NEUMANN, P. 2008. Potential host shift of the small hive beetle (Aethina tumida) to bumblebee colonies (Bombus impatiens). Insectes Soc. (Switzerland). 55(2):153-162. https://doi.org/10.1007/s00040-008-0982-9

17. HUNTER, P.E.; HUSBAND, R.W. 1973. Pneumolaelaps (Acarina: Laelapidae) Mites from North America and Greenland. Florida Entomologist. (United States). 56(2):77-91. https://doi.org/10.2307/3493231

18. HUSBAND, R.W.; BROWN, T.M. 1976. Insects associated with Michigan bumblebees (Bombus spp.). Great Lakes Entomol (United States). 9(1):57-62.

19. KLIMOV, P.B.; OCONNOR, B.; OCHOA, R.; BAUCHAN, G.R.; SCHER, J. 2016. Bee Mite ID: Bee-Associated Mite Genera of the World. USDA APHIS Identification Technology Program (ITP). Available in Internet from: http://www.idtools.org/id/mites/beemites/ (with access on $28 / 09 / 2020)$.

20. KWON, Y.J.; SAEED, S.; DUCHATEAU, M.J. 2003. Control of Plodia interpunctella (Lepidoptera: Pyralidae), a pest in Bombus terrestris (Hymenoptera: Apidae) colonies. Can. Entomol. (England) 135:893-902. https://doi.org/10.4039/n03-013

21. LIÉVANO, A.; OSPINA-TORRES, R.; NATES-PARRA G. 1991. Distribución altitudinal del género Bombus en Colombia. Trianea (Colombia). 4:541-550.

22. MACDONALD, J.F.; MAT'THEWS, R.W.; JACOBSON, R.S. 1980. Nesting biology of the yellow-jacket, Vespula flavopilosa. J. Kansas Entomological Society (United States). 53:448-458. 
23. MAGGI, M.; LUCIA, M.; ABRAHAMOVICH, A.H. 2011. Study of the acarofauna of native bumblebee species (Bombus) from Argentina. Apidologie (France). 42:280-292. https://doi.org/10.1007/s13592-011-0018-8

24. MAJKA, C.; LANGOR, D. 2010. Contributions towards an understanding of the Cryptophaginae (Coleoptera, Cryptophagidae) of Atlantic Canada. ZooKeys (Bulgaria). 35:13-35.

https://doi.org/10.3897/zookeys.35.314

25. MICHENER, C. 2007. The Bees of the Word. The Johns Hopkins University Press (United States). 953p.

26. MORALES, C.L. 2007. Introduction of non native bumblebees (Bombus): causes, ecological consequences and perspectives. Ecología Austral (Argentina). 17:51-65.

27. MOURE, J.S.; MELO, G.A.R. 2012. Bombini Latreille, 1802. In: Moure, J.S.; Urban, D.; Melo, G.A.R. (eds). Catalogue of Bees (Hymenoptera, Apoidea) in the Neotropical Region - online version. Available in Internet at: http://www.moure.cria.org.br/catalogue (with access on 25/04/2021).

28. NELSON, L.A.; WALLMAN, J.F.; DOWTON, M. 2007. Using COI barcodes to identify forensically and medically important blowflies. Med. Vet. Entomol. (England). 21:44-52. https://doi.org/10.1111/j.1365-2915.2007.00664.x

29. PETERSON, A. 1957. Larvae of Insects, Part 2. (United States). 356p.

30. PLISCHUK, S.; FERNÁNDEZ DE LANDA, G.; REVANEIRA, P.; QUINTANA, S.; POCCO, M.E.; CIGLIANO, M.M.; LANGE, C.E. 2020. Parasites and pathogens associated with native bumble bees (Hymenoptera: Apidae: Bombus spp.) from highlands in Bolivia and Peru. Stud Neotrop Fauna E (United Kingdom). 1-6. https://doi.org/10.1080/01650521.2020.1743551

31. POT'TS, S.G.; BIESMEIJER, J.C.; KREMEN, C.; NEUMANN, P.; SCHWEIGER, O.; KUNIN, W.E. 2010. Global pollinator declines: Trends, impacts and drivers. Trends Ecol. Evol. (Netherlands). 25:345-353. https://doi.org/10.1016/j.tree.2010.01.007

32. PRYS-JONES, O.E.; CORBET, S.A. 1991. Bumblebees. Naturalists' handbook series 6. Richmond Publishing Co. (United Kingdom). 92p.

33. REVANEIRA, P.; LUCIA, M.; ABRAHAMOVICH, A.H.; MAGGI, M. 2014. Spatial aggregation of phoretic mites on Bombus atratus and Bombus opifex (Hymenoptera: Apidae) in Argentina. Apidologie (France). 45(5):579-589. https://doi.org/10.1007/s13592-014-0275-4
34. REVANEIRA, P.D.; QUINTANA, S.; DE LANDA, G.F.; ARCERITO, F.M.; LUCÍA, M.; ABRAHAMOVICH, A.H.; PLISCHUK, S.; EGUARA, M.J.; MAGGI, M.D. 2020. Phoretic mites on South American bumblebees (Bombus spp.) as parasite carriers: a historical input. Apidologie (France). 51(4):455-464. https://doi.org/10.1007/s13592-020-00733-w

35. REVANEIRA, P.D.; SALVARREY, S.; SANTOS, E.; ARBULO, N.; INVERNISSI, C.; PLISCHUK, S.; ABRAHAMOVICH, A.; MAGGI, M.D. 2019. Phoretic mites associated to Bombus pauloensis and Bombus bellicosus (Hymenoptera: Apidae) from Uruguay. J. Apic. Res. (United Kingdom). 58(3):455-462.

https://doi.org/10.1080/00218839.2018.1521775

36. ROUBIK, D.; WHEELER, Q. 1982. Flightless beetles and stingless bees: phoresy and scotocryptine beetles (Leiodidae) on their meliponine hosts (Apidae). J. Kans. Entomol. Soc. (United States). 55:125-135.

37. ROYCE, L.A.; KRANTZ, G.W. 1989. Observations on pollen processing by Pneumolaelaps longanalis (Acari: Laelapidae), a mite associate of bumblebees. Exp. Appl. Acarol. (Netherlands). 7:161-165. https://doi.org/10.1007/BF01270436

38. SCHWARTZ, H. 1948. Stingless bees (Meliponidae) of the Western Hemisphere. Bulletin of the American Museum of Natural History (United States). 546p.

39. SPIEWOK, S.; NEUMANN, P. 2006. Infestation of commercial bumblebee (Bombus impatiens) field colonies by small hive beetles (Aetbina tumida). Ecol. Entomol. (England). 31:623628.

https://doi.org/10.1111/j.1365-2311.2006.00827.x

40. TÉLLEZ-FARFÁN, L;; POSADA FLOREZ, F. 2013. Curaduría e identificación de la fauna de Bombus de la colección de entomología de la Universidad de Ciencias Aplicadas y Ambientales U.D.C.A. Rev U.D.C.A. Act \& Div Cient. (Colombia). 16(2):501-509. https://doi.org/10.31910/rudca.v16.n2.2013.924

41. THORP, R.; HORNING, D.; DUNNING, L. 1983. Bumble bees and cuckoo bumble bees of California (Hymenoptera, Apidae). The Regents of the University of California (United States). 78p.

42. VELTHUIS, H.H.W.; VAN DOORN, A. 2006. A century of advances in bumblebee domestication and the economic and environmental aspects of its commercialization for pollination. Apidologie (France). 37:421-451. https://doi.org/10.1051/apido:2006019 
43. WHEELER, W.M. 1919. The phoresy of Antherophagus. Psyche (Egypt). 26(6):145-152.

44. WILLIAMS, J.L. 1997. Insects: Lepidoptera (moths). In: Morse, R.; Flottum, K. (Eds). Honey Bee Pests, Predators, and Diseases (3rd Ed.). (United States). 732p.

45. WILLIAMS, P.; CAMERON, S.; HINES, H.; CEDERBERG, B.; RASMONT, P. 2008. A simplified subgeneric classification of the bumblebees (genus Bombus). Apidologie (France). 39:1-29.

https://doi.org/10.1051/apido:2007052

46. WILLIAMS, P.H.; OSBORNE, J.L. 2009. Bumblebee vulnerability and conservation world-wide. Apidologie (France). 40:367-87.

https://doi.org/10.1051/apido/2009025 